\title{
Lean Six Sigma methods and tools in ISO 9001:2015 management systems
}

\author{
Pedro Alexandre Marques ${ }^{* 1}$, Francisco Frazão Guerreiro ${ }^{2}$, Pedro Manuel Saraiva ${ }^{3}$ \\ ${ }^{1}$ ULHT - Lusófona University of Technologies and Humanities, Dpt. of Industrial Engineering, \\ Faculty of Engineering, Lisbon, Portugal \\ ${ }^{2}$ ISCTE University Institute of Lisbon, Country, Department of Marketing, Operations \& \\ Management, Lisbon, Portugal \\ ${ }^{3}$ University of Coimbra, Department of Chemical Engineering, Faculty of Sciences \& \\ Technologies, Coimbra, Portugal.
}

\begin{abstract}
ISO 9001 companies are adopting continuous improvement systems based on Lean and Six Sigma principles. Objective: this paper aims to illustrate how Lean and Six Sigma principles, methodologies and tools can be adopted within a quality management system based on the ISO 9001:2015 standard. Results: a new Lean Six Sigma and ISO 9001:2015 integration model is proposed with the explanation of how a wide set of Lean and Six Sigma tools and methods can be applied in different clauses of requirements of the standard. Conclusion: the proposed model contributes to increase the ability to combine a quality management system based on ISO 9001:2015 with a Lean Six Sigma improvement program into a single and integrated management system, thus improving overall efficiency.
\end{abstract}

Key words: lean, management, six sigma

\section{INTRODUCTION}

Lean and Six Sigma have become subject of increasing interest from companies of different sectors across the globe [1][2]. On the other hand, one has been witnessing the dissemination of global management system standards, particularly ISO 9001 for quality management systems [3]. Two challenges arise from this reality. First, how can companies develop a continuous improvement program based on Lean and Six Sigma principles and practices, incorporating them into the global quality management system of an organization? Secondly, how can a company comply with the ISO 9001 clauses of requirements by taking advantage of the management practices that are inherent to a continuous improvement program?

The exploitation of synergies between ISO 9001 and Lean and/or Six Sigma have been studied by different researchers, but only a few of them focus on the newest 2015 version of ISO 9001. In this paper, a model to integrate the clauses of ISO 9001:2015 with the principles, methodologies, and tools usually adopted in the context of a Lean Six Sigma program is proposed, by taking advantage of the Annex SL framework, which prescribes how ISO management system standard standards should be written.

This paper is organized around four sections. After reviewing the literature about the integration of Lean and/or Six Sigma with ISO 9001, a new framework to integrate Lean Six Sigma methods and tools in the clauses of requirements of ISO 9001:2015 is presented. Conclusions and future work are discussed in the last section.

\section{LITERATURE REVIEW}

A company-wide improvement initiative is both money and time consuming. It can be only be sustained in the long term if grounded in a proper quality and continuous improvement culture [4]. The hardest thing about Lean is in sustaining improvements, so these would benefit from the standardized process-driven approach required by the ISO 9001 clauses [5]. According to Snee and Hoerl [6], Lean Six Sigma is a very affective project-byproject approach, but it lacks in terms of breadth for not being a complete quality management system (QMS).

Corresponding Author: Pedro Alexandre Marques, ULHT - Lusófona University of Technologies and Humanities, Dpt. of Industrial Engineering, Faculty of Engineering, Lisbon, Portugal 
After the publication of a new version of ISO 9001 in 2000, some models attempting to explore synergies between Lean Six Sigma and that standard were proposed in the literature. Authors such as Warnack [7], Pfeifer et al. [8], and Lupan et al. [9] were the first to come up with integration frameworks, but they were generic and did not specify guidelines about the role that Six Sigma methods and tools could have in the scope of each clause of requirements of ISO 9001. The model suggested by Bewoor and Pawar [10] was the first containing linkages between the clauses of ISO 9001:2000 with Six Sigma; nevertheless, their approach only related the clauses with each of the five stages comprising the DMAIC (Define-Measure-AnalyzeImprove-Control) roadmap of Six Sigma for process improvement. Marques et al. [11] came up with an integration framework, comprising 27 guidelines, to facilitate the articulation of a Six Sigma program with an ISO 9001 QMS, where each guideline was associated to a specific clause of requirements. Karthi et al. [12] introduced the L6QMS-2008 model to integrate DMAIC and the belt-based training infrastructure of a Lean Six Sigma program with the process-based model of ISO 9001:2008, having also developed an alternative version of this standard by adding specific Lean Six Sigma requirements to it.

In terms of proposed models to integrate ISO 9001 with Lean Management, the availability of literature is scarcer. The research developed by Micklewright [5] is likely to be the most profound on the topic. According to the author, Lean Thinking can be used to debureaucratize the processes related to the QMS documentation, as well as to simplify procedures and work instructions. Combining QMS audits with Gemba Walks is another possibility to link Lean and ISO 9001 proposed by the authors, while the use of A3 Problem Solving, a core Lean tool, can be adopted to treat nonconformities and develop corrective actions. Another proposal of Micklewright [5] is to utilize Training Within Industry (TWI), a foundational Lean tool, to foster the competency training system which is addressed in some requirements of ISO 9001. Chiarini [13] provides very detailed mappings between the clauses of ISO 9001:2008 and a wide set of Lean principles and tools, describing integration guidelines for each relationship. Pheng [14] explores how 5S principles can be integrated in some of the ISO 9001:2000 requirements. Sivaram [15] discusses logical connections between Total Productive Maintenance (TPM) and clauses of requirements contained in ISO 9001:2008, proposing a roadmap for an integration.

The integration models proposed in the literature from 2001 to 2015 have their focus on the 2000 and 2008 versions of ISO 9001, whose structure is the same and with a very similar content. The published research regarding the integration of Lean and/or Six Sigma with ISO 9001:2015 is still very scarce. Marques et al. [16] were the first to come up with an integration model between Lean Six Sigma and the newest 2015 version of ISO 9001. The authors proposed a framework, depicted in figure 1, that uses the high-level structure provided by Annex SL of ISO to establish existing linkages between the clauses of requirements contained in ISO 9001:2015 and the activities that usually take place in a Lean Six Sigma program. This integration model assigns the clauses of requirements contained in the standard to the following four life-cycle stages of a continual improvement project:

1. Identification of project candidates.

2. Selection of the most relevant project(s).

3. Planning, execution and completion of a selected project.

4. Post-project activities (e.g. roll-out, lessons learnt, report).

The model does not however describe how Lean and Six Sigma tools can be used in a structured way to perform the activities required by ISO 9001:2015 for a QMS.

More recently, Bacoup et al. [17] suggested a "Lean Normalization" methodology that takes advantage of many existing synergies between ISO 9001 and Lean Thinking. According to the authors, the "Lean Normalization" leads to an integrated and agile QMS called Lean QMS (LQMS) that relies on six core concepts:

1. Elimination of waste: Documentary Muda.

2. Just-In-Time: Right Documents.

3. Continuous improvement: Design of the Continuous Improvement Process.

4. Perfect Quality: Due Quality.

5. Visual Management: Visual Communication

6. Human Resources Management: LQMS Animation. 


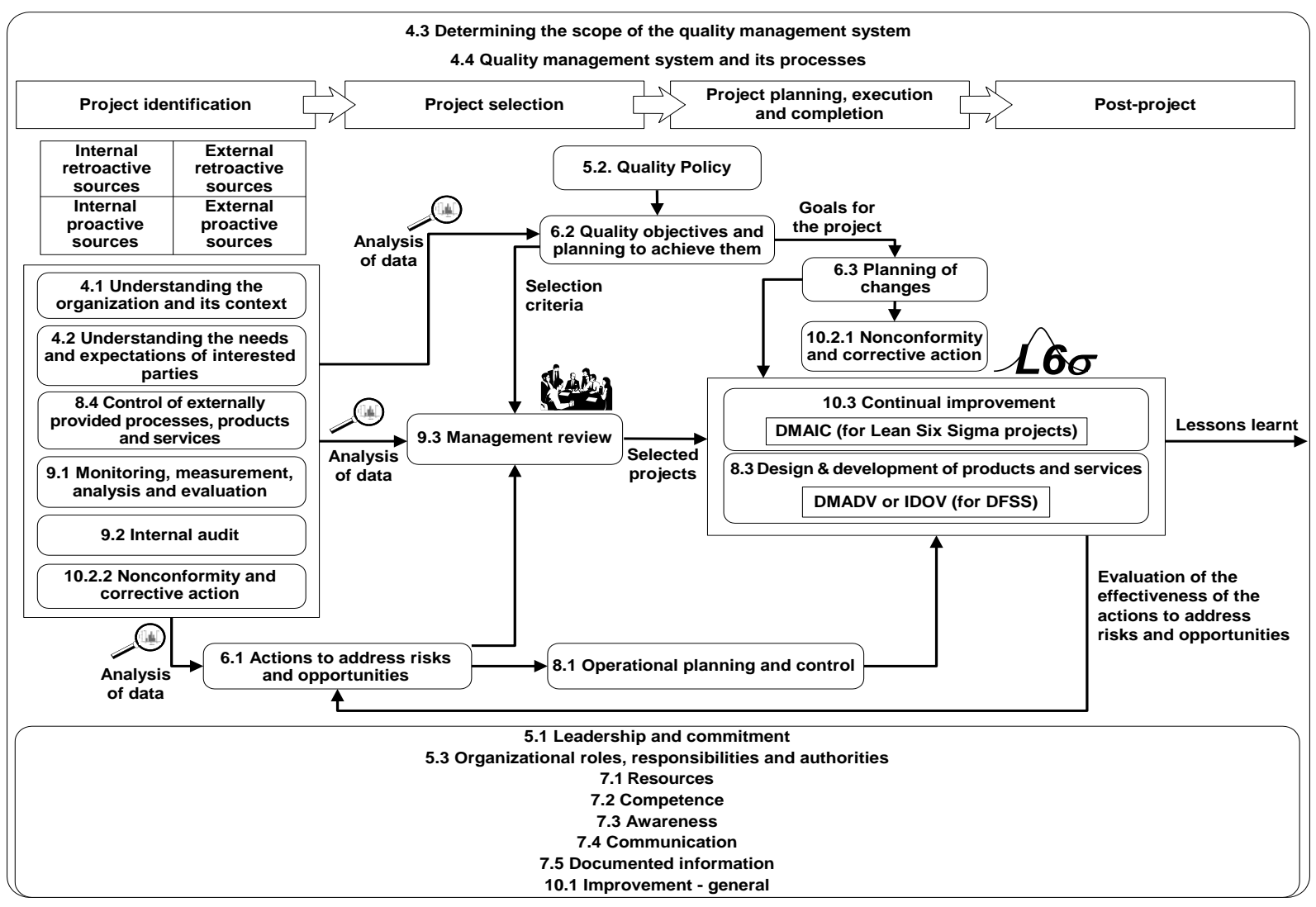

Figure 1 - Model to integrate Lean Six Sigma with ISO 9001:2015 proposed by Marques et al. [16]

\section{PROPOSED APPLICATIOND OF LEAN SIX SIGMA METHODS AND TOOLS IN ISO 9001:2015}

Figure 2 depicts how a wide set of quality and continuous improvement methods, tools and techniques can be adopted in an integrated Lean, Six Sigma and ISO 9001:2015 management system. The model relies on the structure provided by Annex SL. The applicability of the tools and methods will next be explained for all phases of the project life-cycle indicated in the integration framework.

\section{Project identification}

Potential projects derive from opportunities for improvement that are detected based on frequent and systematic analysis of data that have origin in several sources, including:

- Clause 4.1: issues from the external context, such as political, economic, social, technological, legal, and environmental
(PESTLE analysis) facts that might be relevant for the strategy and direction of a company.

- Clause 4.1: recognized internal strengths and weaknesses of the company, as well as of opportunities and threats (SWOT analysis) for the business with origin on elements of the external context, including competition, market evolution, and environment

- Clause 4.2: the needs and expectations of customers and other interested parties, including the employees. A complete identification of interested parties can be done using the Customer Value Chain Analysis [18], while their requirements may be gathered using face-to-face interviews, focus groups, observations, among other Voice of the Customer (VOC) tools. The needs and expectations of the employees can be identified during planned Gemba Walks, where managers go to a direct observation ("go and see") of the Gemba, the locals where operations take place. 
- Clause 8.4: the performance of external suppliers. Sampling procedures for inspection by attributes or by variables are statistical quality control instruments included in the Six Sigma toolbox that can be useful to control and evaluate the performance of external providers.

- Clause 9.1: claims, complaints, suggestions, surveys, and other feedback from customers and other stakeholders are typical but valuable instruments to identify areas for improvement. In addition to these, visual management tools from Lean, including daily Kaizen team boards and mission control (Obeya) rooms, can be helpful to visually display problems and existing gaps between goals (or requirements) and results. Measurement System Analysis (MSA), usually used during the Measure phase of the Six Sigma DMAIC roadmap, may be used to ensure reliable data that will feed key performance indicators used to evaluate the performance of processes, products, and services.

- Clause 9.2: results from Kaizen audits, including $5 \mathrm{~S}$ audits, usually provide a complete set of opportunities for improvement that will generate the portfolio of Gemba Kaizen Events candidates. The Shingo Assessment process [19] enables an organization to evaluate its culture in terms of continuous improvement practices, by analyzing the behavioral adoption of a set of guiding principles. One of the outputs that results from the Shingo Model assessment is the identification of strengths and opportunities for improvement.

- Clause 10.2: results derived from past structured problem-solving events, which are applicable to treat nonconformities and developing corrective actions, are a worth source of information. There are various structured problem-solving tools in the Lean Six Sigma toolbox, including: A3 Problemsolving, 8D methodology, Kobetsu Kaizen (KK), and 3C (Case-Cause-Countermeasure). The way these problem-solving methods are related to the process of treating nonconformities and developing corrective actions are exhibited in figure 5.

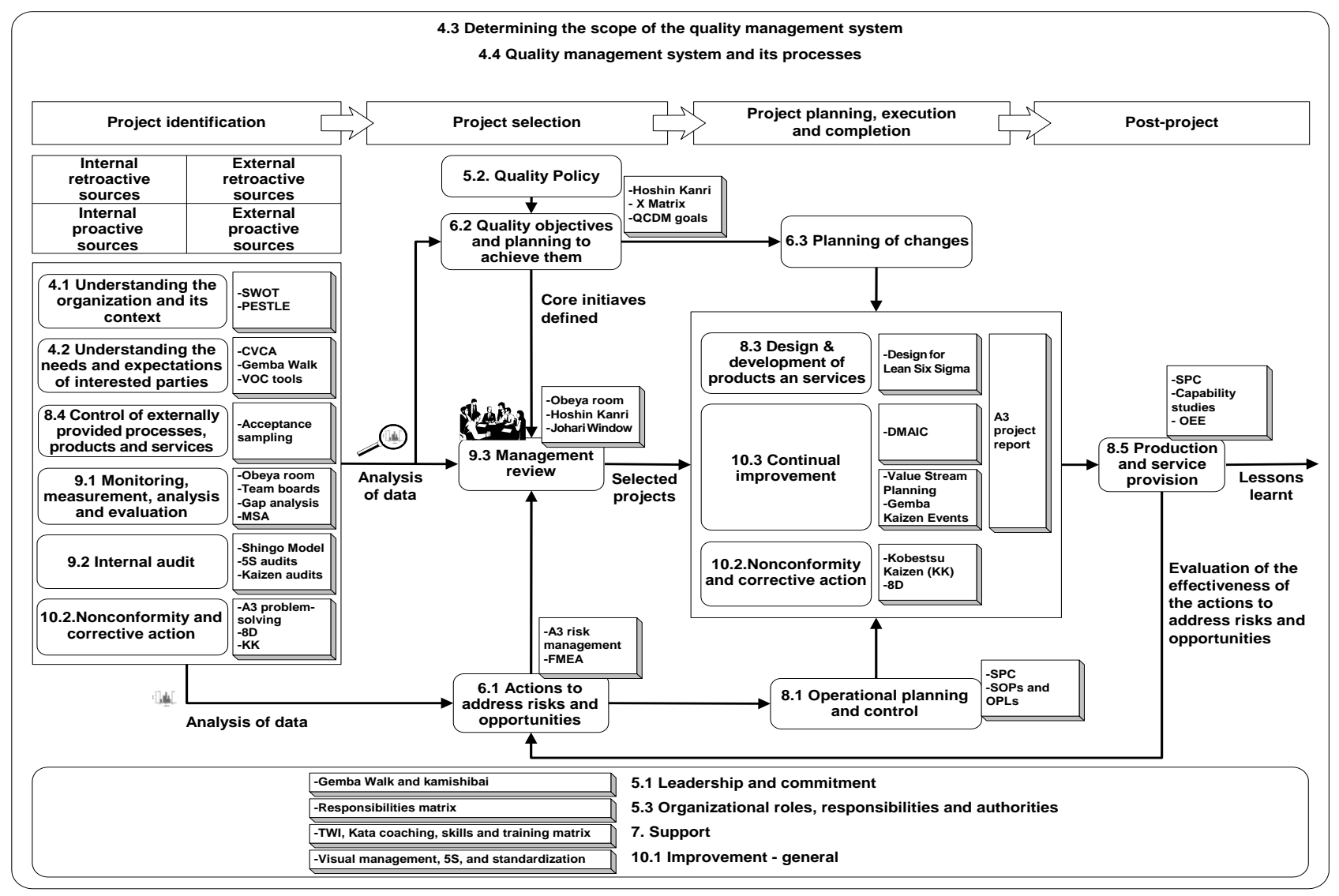

Figure 2 - Application of Lean Six Sigma methods and tools in ISO 9001:2015 


\section{Project selection}

The project identification phase feeds the pipeline of improvement initiatives candidates that needs to be evaluated and prioritized. The most promising initiatives will have a relevant impact on the business results, by increasing processes' efficiency and/or effectiveness as well as on customer satisfaction. The Johari Window is a simple but powerful project selection graph that helps managers to determine which candidates are likely to have the highest impact on business results and the less degree of difficulty.

On the other hand, any selected project needs to be aligned with the enterprise strategy. The $\mathrm{X}$ matrix, a core tool used in the Hoshin Kanri process for strategy planning and deployment, often used in Lean programs, can be customized to set planned quality and improvement initiatives properly aligned with the defined quality objectives (clause 6.2) and with the core guidelines contained in the Quality Policy (clause 5.2) of the company. By using an example, figure 3 illustrates how the X Matrix from Hoshin Kanri can be used in the planning phase of an ISO 9001 quality management system.

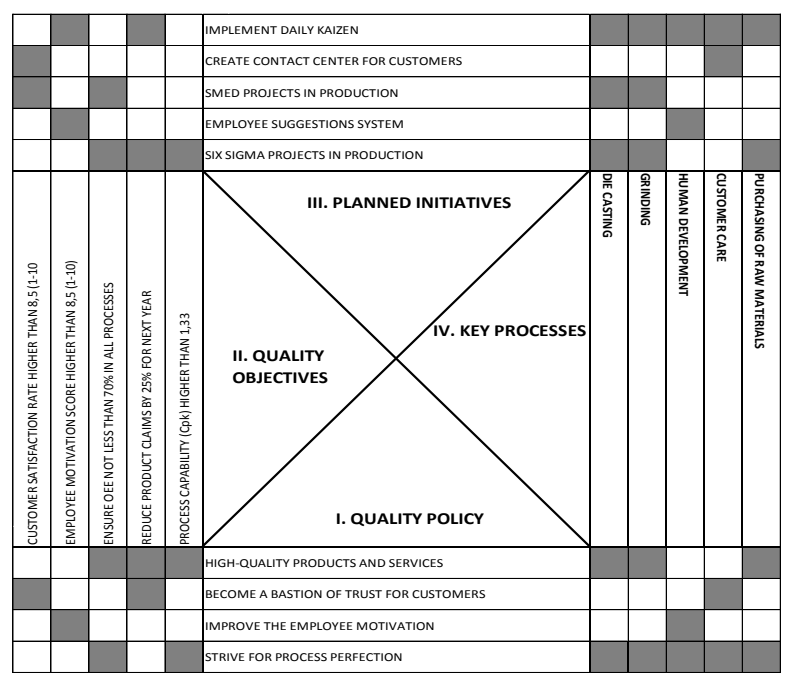

Figure 3 - How to use the X Matrix of Honshin Kanri in the planning of a quality management system

The quality objectives usually fall into one of the following dimensions: Quality (Q), Cost (C), Delivery (D), and Morale (M). Objectives measured by metrics such as the capability indexes ( $\mathrm{Cp}$ and $\mathrm{Cpk}$ ), performance indexes ( $\mathrm{Pp}$ and $\mathrm{Ppk}$ ), proportion of defectives, and throughput yield correspond to the " $Q$ " dimension. Cost of poor quality, inventory holding costs, and productivity are examples of the " $\mathrm{C}$ " dimension. The third category, "D", includes measures like the service level, the delivery lead time, or a machine changeover time. Finally, the "M" dimension comprises employee motivation indicators, safety metrics like the number of accidents, and other people or behavior related measures.

When planning the QMS, the organization determines its risks and opportunities together with planned actions to address them (clause 6.1). The risk-based thinking embedded into the ISO 9001:2015 standard allows a company to develop a proactive and preventive culture to improve processes, products, and services; nevertheless, the standard does not adopt any formal risk management tool. Both Lean and Six Sigma adopts risk management tools that allows any company to materialize the required risk-based thinking. For example, Lean provides a risk management version of A3, where it is possible to visually display identified risk factors, analyze and evaluate the risk magnitude, develop preventive and mitigation actions to minimize risks, and monitor the effectiveness of such actions to reduce risk. Failure Mode and Effect Analysis (FMEA), including Process FMEA and Design FMEA, is a tool used in Six Sigma projects that also comprises all the risk management stages, but it uses a more quantitative approach.

The management review process described by clause 9.3 of ISO 9001:2015 suits the project selection stage very well. Both project selection and the QMS management review shall be conducted by top management to ensure alignment with the strategic direction. The project candidates need to be assessed according to the quality objectives and the planned high-level initiatives derived from the Quality Policy and attending to the risks and opportunities to be addressed. Obeya room, which is mission control room where strategic and project management activities are visually performed, can also be the place to carry out effective management reviews of the quality system.

\section{Project planning, execution, and completion}

Every selected project should be properly planned before starting its execution. To this purpose, a project charter can be used to organize all the relevant project information, including the following:

- Description of the project scope, its boundaries and objectives.

- Key performance indicators to measure the project success.

- Methodology to be followed, including the main stages, their sequence, and deliverables. 
- Team members as well as their roles and responsibilities.

- Predicted dates for starting and ending the project.

- Project schedule in a Gantt chart format.

The project charter can be incorporated in a A3 Project Report to stimulate visual management and a more active involvement from all project team members from the very beginning.

There are various types of improvement initiatives, from focused problem-solving activities to the design of new products, services or processes. The adoption of a certain improvement approach depends on the degree of improvement that is intended to introduce. This is illustrated in figure 4. For instance, a Gemba Kaizen Event usually introduces more evolutive changes in a process when compared with a Lean Six Sigma project; however, the latter is less disruptive than Design for Lean Six Sigma. There are two Design for Lean Six Sigma roadmaps: 1) IDOV (Identify-Design-OptimizeValidate) used to design and develop new systems, processes and products/services; 2) DMADV (DefineMeasure-Analyze-Design-Verify) for redesigning existing ones. Both IDOV and DMADV can be used in the context of clause 8.3 (requirements for the design and development of products and services), but IDOV is more disruptive than DMADV.

\begin{tabular}{|c|c|c|c|c|c|}
\hline \multirow{6}{*}{ 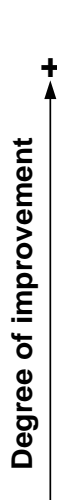 } & Approach & Methodology & Scope & Typical duration & ISO 9001:2015 clauses \\
\hline & \multirow{2}{*}{$\begin{array}{l}\text { Design for Lean } \\
\text { Six Sigma }\end{array}$} & IDOV & $\begin{array}{l}\text { Design of new products, services } \\
\text { and/or processes }\end{array}$ & \begin{tabular}{|c|}
6 months to \\
more than 1 year
\end{tabular} & \multirow{2}{*}{$\begin{array}{l}\text { 8.3. Design and } \\
\text { development of } \\
\text { products and services }\end{array}$} \\
\hline & & DMADV & $\begin{array}{l}\text { Redesign of existing products, } \\
\text { services and/or processes }\end{array}$ & 4-9 months & \\
\hline & Lean Six Sigma & DMAIC & $\begin{array}{l}\text { Significant improvement of an } \\
\text { existing process }\end{array}$ & 2-6 months & \multirow{2}{*}{$\begin{array}{l}\text { 10.3. Continual } \\
\text { improvement }\end{array}$} \\
\hline & Kaikaku & $\begin{array}{c}\text { Gemba Kaizen } \\
\text { Event }\end{array}$ & $\begin{array}{l}\text { Improvement of an existing } \\
\text { process }\end{array}$ & $3-10$ days & \\
\hline & $\begin{array}{c}\text { Structured } \\
\text { problem-solving }\end{array}$ & $\mathrm{A3}, \mathrm{KK}, 8 \mathrm{D}, 3 \mathrm{C}$ & $\begin{array}{l}\text { Analysis of causes and definition } \\
\text { of solutions for a specific problem }\end{array}$ & $\begin{array}{c}\text { Less than } 1 \\
\text { week }\end{array}$ & \begin{tabular}{|c|}
$\begin{array}{c}\text { 10.2. Noconformity and } \\
\text { corrective action }\end{array}$ \\
\end{tabular} \\
\hline
\end{tabular}

Figure 4 - Different improvement approaches, their applicability and relationship with ISO 9001:2015

All structured problem-solving approaches, regardless of the specific methodology, follow the reasoning behind the requirements contained in clause 10.2. The process to treat nonconformities and develop corrective actions follows the sequence of steps adopted by all structured problem-solving methods, as depicted in figure 5 .

The A3 Project Report tool can be used to present status to top management of a certain improvement or design project. The status presentation usually takes place in an Obeya room.

\section{Post-project}

In the post-project stage, it is important to track in what extent the project results contributed to increase process performance and they contributed to address risks and opportunities (clause 6.1). The lessons learnt from a completed project should also be captured and recorded, which will benefit future initiatives. After an improvement initiative, it is important to ensure that processes, including productive and service provision processes, remain

stable and maintain the new enhanced performance. Statistical Process Control (SPC) and capability studies may be important at this point, as well as the measurement of the Overall Equipment Effectiveness (OEE) to assess process performance. 


\begin{tabular}{|c|c|c|c|c|}
\hline \begin{tabular}{|c|}
$\begin{array}{c}\text { Treatment of nonconformities } \\
\text { (ISO 9001:2015) }\end{array}$ \\
\end{tabular} & A3 Problem Solving & Kobetsu Kaizen (KK) & $\begin{array}{l}\text { Eight Disciplines of } \\
\text { Problem Solving (8D) }\end{array}$ & $\begin{array}{c}\text { Case-Cause- } \\
\text { Countermeasure (3C) }\end{array}$ \\
\hline Identify the nonconformity & \multirow{2}{*}{$\begin{array}{l}\text { Characterize the } \\
\text { problem }\end{array}$} & Selection of the problem & Form a team & \multirow{4}{*}{ Case } \\
\hline $\begin{array}{l}\text { React to the effect with } \\
\text { immediate actions }\end{array}$ & & Deccribe the nroblem & Describe the problem & \\
\hline \multirow{2}{*}{$\begin{array}{c}\text { Analyze and understand the } \\
\text { nonconformity }\end{array}$} & $\begin{array}{c}\text { Describe current } \\
\text { situation }\end{array}$ & Descrioe tne probiem & \multirow{2}{*}{$\begin{array}{l}\text { Interim containment } \\
\text { action }\end{array}$} & \\
\hline & Define future situation & Define objectives & & \\
\hline $\begin{array}{l}\text { Determine the causes of the } \\
\text { nonconformity }\end{array}$ & $\begin{array}{l}\text { Analyze causes of the } \\
\text { problem }\end{array}$ & $\begin{array}{c}\text { Analyze causes of the } \\
\text { problem }\end{array}$ & Root cause analysis & Cause \\
\hline Develop corrective actions & $\begin{array}{c}\text { Establish } \\
\text { countermeasures }\end{array}$ & \multirow{2}{*}{ Define solutions } & $\begin{array}{c}\text { Permanent corrective } \\
\text { action (PCA) }\end{array}$ & \multirow{2}{*}{ Countermeasure } \\
\hline Implement corrective actions & $\begin{array}{c}\text { Implement } \\
\text { countermeasures }\end{array}$ & & \multirow{2}{*}{$\begin{array}{l}\text { Implement and validate } \\
\text { PCA }\end{array}$} & \\
\hline $\begin{array}{c}\text { Review the effetiveness of } \\
\text { the corrective actions }\end{array}$ & \multirow{3}{*}{ Monitor and validate } & $\begin{array}{c}\text { Verify effectiveness of } \\
\text { solutions }\end{array}$ & & \multirow{3}{*}{ Check results } \\
\hline \multirow{2}{*}{$\begin{array}{l}\text { Prevent nonconformity to } \\
\text { recur }\end{array}$} & & Standardize solutions & Prevent recurrence & \\
\hline & & Communicate activities & $\begin{array}{l}\text { Closure and team } \\
\text { celebration }\end{array}$ & \\
\hline
\end{tabular}

Figure 5 - Relationship between process to treat nonconformities of ISO 9001:2015 and different problem-solving methodologies

\section{Support clauses}

Some of the ISO 9001:2015 clauses are transversal to the whole project life-cycle. The most obvious case are the requirements under section 7 , designated as "Support", since a Lean Six Sigma program requires resources, development of peoples' skills and competences through training, coaching, and other related systems, as well as documentation management rules. Lean provides some useful tools in this context, such as for example Kata coaching and Training Within Industry (TWI) that help employees to learn quicker and more effectively a certain task or procedure.

Top management must demonstrate leadership and commitment (clause 5.1) not only with respect to the QMS but also to the continual improvement system based on Lean and/or Six Sigma principles. Scheduled Gemba Walks and the use of reinforcing behavior cards (kamishibai) are instruments by which top managers can demonstrate their commitment. Roles, responsibilities, and authorities (clause 5.2) inherent to a Lean Six Sigma program may be visually displayed in a responsibilitiestype matrix.

Basic stability Lean tools, namely visual management, $5 \mathrm{~S}$, and standardization provide the necessary foundations for any improvement (clause 10.1) system.

\section{CONCLUSIONS AND FUTURE WORK}

This paper proposes an integration model between ISO 9001:2015 and a Lean Six Sigma program to guide managers in the use of a wide set of quality and continuous improvement tools within the context of that international standard. The framework takes advantage of the Annex SL structure to link the typical project lifecycle stages with the standard's clauses. It provides a valuable support in the choice of the right Lean and Six Sigma tools and methods during the activities that shall take place in any quality management system as well as in the development of different types of improvement initiatives. This paper details the role that those methods and tools can have in the identification of project candidates, the prioritization of the most promising ones, during the planning, conduction, and completion of each selected initiative, and in the post-project activities. The proposal allows any type of organization to implement and maintain an efficient integrated quality and improvement management system that takes advantage of the natural synergies between Lean, Six Sigma, and ISO 9001:2015. As a future research, the model will be extended to the integration with other international management system standards, particularly with 
environmental (ISO 14001:2015) and health and safety management (ISO 45001:2018) systems.

\section{REFERENCES}

[1]Yadav, G and T. Desai, 2016. Lean Six Sigma: a categorized review of the literature. International Journal of Lean Six Sigma, 7(1): 2-24.

[2]Boykin, R., 2015. Enterprise Resource Planning and Lean Six Sigma. In: Tetteh, E.G. and B.M. Uzochukwu (eds). Lean Six Sigma approaches in manufacturing, services, and production, 27-54. IGI Global, USA.

[3]Heras-Saizarbitoria, I, O. Boiral and E. Allur, 2018. Three decades of dissemination of ISO 9001 and two of ISO 14001: Looking back and ahead. In: HerasSaizarbitoria, I. (eds) ISO 9001, ISO 14001, and new management standards. Measuring Operations Performance, 1-15; Springer, Switzerland.

[4]Plenert, G., 2018. Discover Excellence: an overview of the Shingo Model and its guiding principles. CRC Press, USA.

[5]Micklewright, M., 2010. Lean ISO 9001: Adding spark to your QMS and sustainability to your Lean efforts. ASQ Quality Progress, Milwaukee, WI, USA.

[6]Snee, R.D. and R.W. Hoerl, 2017. Time for Lean Six Sigma 2.0?. Quality Progress, 50(5): 50-53.

[7]Warnack, M., 2003. Continual improvement programs and ISO 9001:2000. Quality Progress, 36(3): 725-743.

[8]Pfeifer, T., W. Reissiger and C. Canales, 2004. Integrating Six Sigma with quality management systems. The TQM Magazine, 16(4): 241-249.

[9]Lupan, R., I.C. Bacivarof, A. Kobi and C. Robledo, 2005. A relationship between Six Sigma and ISO 9001:2000. Quality Engineering, 17(4): 719-725.

[10]Bewoor, A.K. and M.S. Pawar, 2010. Mapping macro/micro level critical links for integrating Six Sigma DMAIC steps as a part of company's existing QMS: an Indian SME case study. International Journal of Six Sigma and Competitive Advantage, 6 (1/2): 105 131.

[11]Marques, P.A., J.G. Requeijo, P.M. Saraiva and F.J. Frazão-Guerreiro, 2013. Integrating Six Sigma with ISO 9001. International Journal of Lean Six Sigma, 4(1): 3659.

[12]Karti, S., S. Devadasan, K. Selvaraju, C.G. Sreenivasa and N.M. Sivaram, 2015. Transforming into a Lean Six Sigma enterprise through ISO 9001 standardbased quality management system. Journal of Enterprise Transformation, 4(2): 100-122.

[13] A. Chiarini, 2011. Integrating lean thinking into ISO 9001: a first guideline. International Journal of Lean Six Sigma, 2(2): 96-117.

[14]Pheng, L., 2001. Towards TQM: integrating Japanese 5-S principles with ISO 9001:2000 requirements. The TQM Magazine, 13(5): 334-341.

[15]Sivaram, N.M., S.R. Devadasan, C.G Sreenivasa, S. Karthi and S. Murugesh, 2012. A literature review on the integration of Total Productive Maintenance elements with ISO 9001 standard. International Journal of Productivity and Quality Management, 9(3): 281308.

[16]Marques, P.A., P. Meyrelles, P. Saraiva and F. Frazão-Guerreiro, 2016. Integrating Lean Six Sigma with ISO 9001:2015. Proceedings of the 2016 IEEE international Conference on Industrial Engineering and Engineering Management. 4-7 December: 898-898.

[17]Bacoup. P., G. Habchi and M. Pralus, 2018. From a Quality Management System (QMS) to a Lean Quality Management System (LQMS). The TQM Journal, 30(1): 20-42.

[18]Donaldson, K.M., K. Ishii and S. Sheppard, 2006. Customer Value Chain Analysis. Research in Engineering Design, 16(4): 174-183.

[19]Plenert, G., 2018. Discover Excellence: An overview of the Shingo Model and its guiding principles. CRC Press, FL, USA. 